\section{Turning down the lights}

\section{London}

SPAIN has become the first country to take central government action to tackle the problem of the glare from artificial lighting that can wreck astronomers' observations. A new law introduced by the science minister, Javier Solana, will place strict controls on lighting on La Palma, Canary Islands, the site of several optical telescopes including the 4.2-metre AngloDutch William Herschel Telescope.

Professor Alec Boksenberg, director of runs the Herschel Telescope), says the new law is a real commitment, "not just empty words", as it sets up a fund of 300 million pesetas ( $£ 1.5$ million) to pay for improvements to existing lighting over the next three years.

'Light pollution' has not yet created serious problems at La Palma, and the new legislation should avert any future difficulties. But US astronomers have already been badly affected. The Mount Wilson Observatory, once one of the world's leading astronomical facilities, can now usefully observe only the brightest stars because the lights of Los Angeles have brightened the night sky by a hundred

US moves to fight light pollution have been taken at city and county level, through local ordinances controlling street lighting and illuminated advertising hoardings. David Crawford, of the Kitt Peak National Observatory in Arizona, says there have been some successes. During the 1980s, the sky above Kitt Peak the Royal Greenwich Observatory (which times over the natural background.

did not become significantly brighter, despite the growth of nearby cities.

But the skies above smaller observatories are still brightening rapidly, and Crawford has set up the International

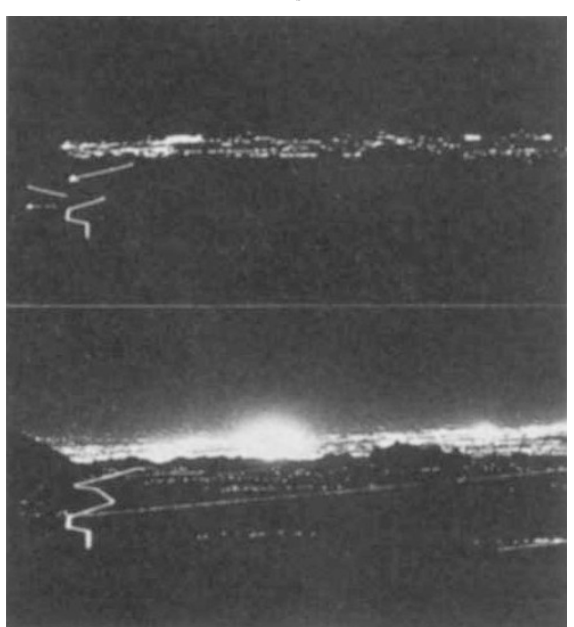

The view from Kitt Peak National Observatory towards Tuscon, Arizona. 'Seeing' was much better in 1959 (top) than in 1980. By the mid1980 s sky brightness had decreased as a result of controls on exterior lighting, although the town had continued to grow. (NOAO).

Dark Sky Association to publicize the problem. Energy-efficiency pressure groups are an important ally. The need is for street lights that direct light downwards, with little 'leakage' up into the night sky. The United States currently "spends more than a billion dollars a year just lighting up the sky", Crawford says.

Peter Aldhous ARCHAEOLOGY

\section{Investigation of Indian bones legal}

\section{Washington}

ONLY a week ago, California archaeologist David Van Horne was facing a stiff prison term for sending two unidentified coinsized bones to a laboratory to have them tested for human origin.

Tried under California law, which makes it a felony to desecrate Indian gravesites, Van Horne could have been sentenced to three years in a state penitentiary if found guilty. But in a precedentsetting decision, municipal judge $B$. J. Bjork late last week ruled that bones even Indian bones - are "archaeological material" until they have been identified

The case had brought dozens of archaeologists - some with bumper stickers reading "Archaeology is Not a Crime" - to the courthouse in support of Van Horne, who has been a vocal critic of California's restrictive rules on investigating Indian remains. Van Horne was charged after his firm, Archaeological as human remains, and freed Van Horne.
Associates, had been hired to survey a construction site for possible Indian artefacts. He found two small bone chips that could not be positively identified as human, so he sent them to a University of California laboratory for analysis. When they turned out to be prehistoric human remains, Van Horne was charged with desecration of an Indian gravesite. The prosecution argued that he should have recognized the small charred bones as Indian remains.

Van Horne claims that he was picked on by local prosecutors for his views. "There is some question if this was malice on the part of the state", he says. In a previous case involving two small milling stones, he lost and was forced to rebury the stones, although he publicly ridiculed the state for spending $\$ 150,000$ to "bury two rocks". "It's a science versus superstition issue. It's nearly impossible to overcome the public guilt over native Americans", he says.

Christopher Anderson

\section{Lower dose limits}

\section{London \& Boston}

THE International Commission on Radiological Protection (ICRP) has reduced its recommended limits for radiation doses received at work. Long-running studies have shown that the risks to health from radiation exposure are about three times higher than was thought in 1977 , when the previous limits were issued.

The survivors of the Hiroshima and Nagasaki atomic bombs have been studied to estimate the risk of developing cancer through radiation exposure: as the population has aged, more survivors have succumbed to cancer than was expected. Recent animal studies have also shown that radiation is more likely to cause heritable genetic defects than was thought.

In 1977, ICRP recommended that workers should receive no more than 50 millisieverts ( $\mathrm{mSv}$ ) each year. This is still the maximum dose in any one year, but ICRP now also recommends that exposure should be kept below an average of 20 $\mathrm{mSv}$ per year over a given five-year period.

The ICRP limits have no legal standing, but they have provided an international standard on which national limits can be based.

The United Kingdom has been relatively quick to take note of its recommendations and adopted the 1977 limits as the legal limits in 1985. If the new recommendations are now adopted, they will affect only a small number of workers, most of them working either in the nuclear industry or in mines where radon gas might be inhaled. At the Sellafield nuclear waste reprocessing plant, for example, where radiation exposure has been linked to the occurrence of leukaemia in the children of workers in a controversial epidemiological study (see Nature 343, 679; 22 February 1990), 44 workers received more than $20 \mathrm{mSv}$ in 1989-90.

The United States has been much slower to take note of ICRP recommendations, and even now the Nuclear Regulatory Commission (NRC) is only just formally adjusting its radiation exposure limits for workers to correspond to the 1977 recommendations. Workers will be allowed no more than an effective dose equivalent of $50 \mathrm{mSv}$ per year (or $5 \mathrm{rem}$ ).

The new limits will lower the maximum permissible annual dose of radiation, but critics in the United States complain that the new rules lag behind international standards and also that they allow loopholes that permit workers in some cases to be exposed to even larger doses of radiation than previously permitted by the NRC. Peter Aldhous \& Seth Shulman 